Personalidade Acadêmica Homenageada:

Augustus B. Cochran III (Agnes Scott College)

\title{
A BUSCA DOS HAITIANOS PELO "SONHO BRASILEIRO": A REAL GARANTIA DE DIREITOS DOS IMIGRANTES NO BRASIL
}

\section{HAITIAN SEARCH FOR “BRAZILIAN DREAM": THE REAL GUARANTEE OF IMMIGRANTS 'RIGHTS IN BRAZIL}

\section{LARA SILVA MELO}

Graduanda em Direito, modalidade integral, pela Escola Superior Dom Helder Câmara. Belo Horizonte-MG. E-mail: larinhasmelo@gmail.com.

\section{CAIO AUGUSTO SOUZA LARA}

Mestre e Doutor em Direito pela Faculdade de Direito da Universidade Federal de Minas Gerais - UFMG. Professor da Escola Superior Dom Helder Câmara. Pesquisador Associado ao Programa RECAJ-UFMG - Acesso à Justiça e Solução de Conflitos. Secretário de Comunicação do Conselho Nacional de Pesquisa e Pósgraduação em Direito - CONPEDI. Belo Horizonte - MG. E-mail: caiolarabh@yahoo.com.br.

RESUMO

A pesquisa que se desenvolve é sobre a violação dos direitos dos haitianos que emigraram ao Brasil. O tema-problema vai retratar a realidade desse povo, como os desafios enfrentados por eles em seu cotidiano, as causas e consequências da imigração e os principais direitos violados. É muito importante que de ênfase a esse tema, pelo fato da violação dos direitos desses imigrantes, e os desafios encontrados por eles ao se inserirem em um novo país com uma nova cultura, e costumes. Além disso, há muitos países que não garantem os direitos, 


\section{Personalidade Acadêmica Homenageada:}

\section{Augustus B. Cochran III (Agnes Scott College)}

apesar da ACNUR (Alto Comissariado das Nações Unidas para os refugiados) buscar garantir esses direitos, dar apoio e proteção aos refugiados. O desastre natural que ocorreu em 2010 agravou mais ainda a situação daquele povo, pois o governo não disponibiliza assistência à sua população, como a falta de saneamento básico, e auxilio medico ineficiente devido a sua atual situação econômica. No Brasil, os haitianos recebem, em geral, o visto de trabalho. A Consolidação das Leis do Trabalho- CLT, conforme artigo 352 a 371 garante direitos trabalhistas aos imigrantes no país, porém tais direitos sociais desses imigrantes não estão sendo respeitados. Além da xenofobia, há também atitudes discriminatórias e obstáculos legais relativos à documentação que culminam a certas dificuldades de integração social. Não obstante a exploração do trabalho, há também preconceito, xenofobia, e dificuldade de aprendizado da língua portuguesa, e a questão da moradia. Assim, é de grande importância a análise das causas e consequências da vinda dos haitianos para o Brasil, para que se compreenda a atual situação social e politica de tal povo. Os refugiados ambientais não possuem proteção jurídica internacional e nacional, por não se enquadrarem na definição de refugiado. O problema objeto da investigação científica proposta é: quais são os principais direitos violados dos haitianos atualmente no Brasil? A partir das reflexões preliminares sobre o tema, é possível afirmar inicialmente que os haitianos ao se inserirem em um novo país se deparam com muitos obstáculos, e desafios, como o preconceito racial, xenofobia, a exploração no mercado de trabalho, as péssimas condições de vida, tendo seus direitos básicos violados. O objetivo geral do trabalho é analisar a atual realidade dos haitianos, e verificar o quanto a realidade de minorias se contradiz à legislação que garante todos os direitos naturais e básicos. É possível constatar que além da busca pelos seus direitos que muitas das vezes é frustrante, esse povo ainda sofre o preconceito, por apresentar cultura e valores distintos dos nossos. Ao verificarmos os fatores de tal imigração conseguimos relacionar a escolha dos haitianos ao decidirem sair de seu país. A violação dos seus direitos no Brasil, só agrava mais a situação psicológica de tais povos, já que a experiência pelas quais esses imigrantes passam podem desencadear transtornos mentais. De fato, o egocentrismo e o individualismo tem sido marcante na nossa sociedade. Portanto, é importante que 


\section{Personalidade Acadêmica Homenageada:}

\section{Augustus B. Cochran III (Agnes Scott College)}

olhemos para o mundo com outra visão, saindo de nossa própria bolha. Assim um dos objetivos dessa pesquisa é mostrar que além da nossa realidade, existem muitas minorias que lutam pelos seus direitos e que vivem em verdadeiro estado de sofrimento. De fato, é necessário que seja criado leis específicas para tratar a questão da inserção dos imigrantes e refugiados no Brasil e a garantia de seus direitos, além da necessidade de políticas públicas que visem proteger e apoiar tais povos. A pesquisa que se propõe pertence à vertente metodológica jurídicosociológica. No tocante ao tipo de investigação, foi escolhido, na classificação de Witker (1985) e Gustin (2010), o tipo jurídico-projetivo. O raciocínio desenvolvido na pesquisa será predominantemente dialético.

PALAVRA-CHAVE: Direitos Humanos; Refugiados Haitianos; Refugiados Ambientais; Garantia de Direitos.

\section{REFERÊNCIAS}

BORBA, Daniel Allan Miranda; FREITAS, Janaina Helena de. Violação dos direitos humanos dos imigrantes haitianos no Brasil: apontamentos sobre as origens deste problema e a atuação do poder judiciário. Disponível em: http://enpejud.tjal.jus.br/index.php/exmpteste01/article/view/307/93. Acesso em: 20 abr. 2019.

DUTRA, Cristiane. Além do Haiti: uma análise da imigração haitiana para o Brasil. Rio de Janeiro: Lumen Juris, 2016.

GUSTIN, Miracy Barbosa de Sousa; DIAS, Maria Tereza Fonseca. (Re)pensando a pesquisa jurídica: teoria e prática. 3ª̣. ed. Belo Horizonte: Del Rey, 2010.

DINIZ, Aline. Imigrantes haitianos sofrem com xenofobia no trabalho. O Tempo. Belo Horizonte, 12 de dezembro de 2016. Disponível em: https://www.otempo.com.br/cidades/imigrantes-haitianos-sofrem-com-xenofobia-notrabalho-1.1410725. Acesso em 20 maio 2019.

MELEU, Marcelino da Silva; BANDEIRA, Lais Cristina. A síndrome do sobrevivente a imigração haitiana: uma análise das consequências da governança por números. ISNN: 2316-753X. Revista Jurídica - Unicuritiba. Vol. 02, n. 51, Curitiba, 2018. Disponível 
Personalidade Acadêmica Homenageada:

Augustus B. Cochran III (Agnes Scott College)

http://revista.unicuritiba.edu.br/index.php/RevJur/article/view/2823/371371486. Acesso em: 22 maio 2019.

SALVO, Katia de Almeida. Os Imigrantes e refugiados haitianos no Brasil e a violação de seus direitos trabalhistas. Bem Paraná. 25 de maio de 2017. Disponível em: https://www.bemparana.com.br/noticia/os-imigrantes-e-refugiados-haitianos-nobrasil-e-a-violacao-de-seus-direitos-trabalhistas--\#.XOWIKIhKhPZ. Acesso em: 20 de maio de 2019.

WITKER, Jorge. Como elaborar una tesis en derecho: pautas metodológicas y técnicas para el estudiante o investigador del derecho. Madrid: Civitas, 1985. 